\title{
Formaldehyde content of milk. 1. Cows fed on protein concentrates treated with different amounts of formal- dehyde
}

\author{
LIISA SYRJÄLÄ-QVIST and JOUKO SETÄLÄ \\ Department of Animal Husbandry, University of Helsinki, \\ SF-00710 Helsinki 71
}

\begin{abstract}
The formaldehyde content was determined on the milk of four dairy cows fed on protein concentrates treated with increasing amounts of formaldehyde 1) 0,2$) 0.8,3) 2.4$ and 4) $4.0 \mathrm{~g} \mathrm{HCHO} / 100$ $\mathrm{g}$ crude protein. The experiment was arranged according to a $4 \times 4$ Latin square design and each test period lasted 10 days. The average milk yield of the cows during the experiment was $9.4 \mathrm{~kg} /$ day.

The protein concentrate was a mixture of soybean meal, skimmed-milk powder, meat-bone meal, brewer's grains, molasses, molassed beat pulp and urea, and the basic feeds were hay, straw and barley. The $\mathrm{HCHO}$-treated protein constituted $\mathbf{4 2 - 5 0} \%$ of the total crude protein of the diet.

The daily amounts of formaldehyde received by the cows on the different diets were: 1) $0 \mathrm{~g}, 2) 2.9 \mathrm{~g}, 3$ ) $5.1 \mathrm{~g}$ and 4) $14.6 \mathrm{~g}$, and the formaldehyde contents per kg of milk were, respectively, 1) $0.2 \mathrm{mg}, 2) 0.3 \mathrm{mg}$, 3) $0.6 \mathrm{mg}$ and 4) $1.7 \mathrm{mg}$. Thus the milk samples contained formaldehyde even when the protein had not been treated. Of the formaldehyde added to the feeds, only $0.06-0.07 \%$ was found in the milk. The formaldehyde content of the milk reached a constant level within the first two days of the test period.
\end{abstract}

\section{Introduction}

One of the methods of improving protein utilization by ruminants is protection of the feed protein against degradation in the rumen. Formaldehyde has been used for this purpose in silage preservation and in the treatment of protein concentrates. When such additives are used, it is important to know how they behave in the metabolism of the animal, and the excretion of formaldehyde in the milk, faeces and urine has been investigated in many experiments (BECK and GROSS 1973, KREULA and RAURAMAA 1976, 1977, WRENN et al. 1976, KAEMMERER and KERBER 1977, KAUFMANN and LÜPPING 1978, SYRJÄLÄ et al. 1978). However, somewhat varying results have been obtained especially as regards the occurrence of formaldehyde in milk.

The purpose of this study was to obtain more information about the formaldehyde content of the milk, when the cows were fed formaldehydetreated feeds. The results reported in this paper are from an experiment 
where the protein concentrate mixture was treated with increasing amounts of formaldehyde. The second part of this study (SYRJÄLÄ-QVIST and SETÄLÄ 1982) deals with cows fed on formaldehyde-treated urea and grass silage preserved with formaldehyde-containing additives.

\section{Experimental procedures}

\section{Feeds and feeding}

The experiment was performed with four dairy cows according to a $4 \times 4$ Latin square. Each experimental period lasted 10 days.

The basic feeds were hay, straw and ground barley. The protein concentrate mixture contained soybean meal $15 \%$, skimmed-milk powder $15 \%$, meat-bone meal $15 \%$, brewer's grains $20 \%$, molasses $8 \%$, molassed beet pulp $10 \%$, urea $4 \%$ plus minerals and vitamins. This protein concentrate mixture was treated with different amounts of Viher solution $(20 \%$ formaldehyde and $30 \% 80$ - $\%$ acetic acid), corresponding to the following concentrations of formaldehyde:

1) Untreated $=\mathrm{HCHO}_{0}$ diet

2) $0.8 \mathrm{~g}$ formaldehyde $/ 100 \mathrm{~g}$ crude protein $=\mathrm{HCHO}_{0.8}$ diet

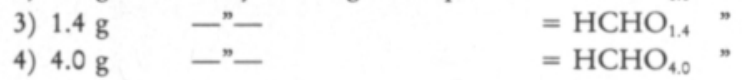

Immediately after addition of formaldehyde the protein concentrate mixtures were packed into plastic bags in order to prevent evaporation of the formaldehyde. The protein concentrate was mixed with the barley meal just before feeding.

The animals were fed individually twice a day. The daily diet consisted of $1.5 \mathrm{~kg}$ protein concentrate mixture and $2-4 \mathrm{~kg}$ hay, $2-4 \mathrm{~kg}$ straw and $3-6 \mathrm{~kg}$ barley, adjusted according to the nutrient requirement (BREIREM 1969). The protein content of the whole ration was $14-15 \%$ of the dry matter. Of this protein, $42-50 \%$ was treated with formaldehyde in the $\mathrm{HCHO}_{0.8}, \mathrm{HCHO}_{1.4}$ and $\mathrm{HCHO}_{4.0}$ diets.

\section{Sampling and analyses}

The chemical composition of the feeds and the amount of free formaldehyde were determined in every period. The milk produced was weighed and sampled at every milking during the five first days of the periods. Formaldehyde was determined on all the samples by the method of BECK and GROSS (1973) with slight modification (ANON 1975, see also KREULA and RAURAMAA 1976). 


\section{Results and discussion}

All the milk samples contained formaldehyde (Fig. 1), even those taken when the feeds were not treated with formaldehyde. Within two days from the start of the test period, the formaldehyde content of the milk reached the level at witch it remained during the rest of the period. The average formaldehyde contents per $\mathrm{kg}$ milk on the different diets were then as follows:

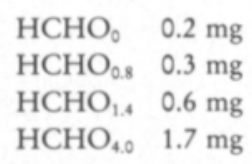

The daily amounts of formaldehyde received by the cows on the different diets were: $\mathrm{HCHO}_{0.8} 2.9 \mathrm{~g}, \mathrm{HCHO}_{1.4} 5.1 \mathrm{~g}$ and $\mathrm{HCHO}_{4.0} 14.6 \mathrm{~g}$ (Fig. 2), and the percentages of these amounts in the milk were only $0.06,0.07$ and 0.07 , respectively. The average daily milk yield on the different diets was 9.4 kg per cow.

Fig. 1. Formaldehyde content of milk when protein concentrate mixture was treated with different amounts of formeldehyde, g $\mathrm{HCHO} / 100$ g crude protein $(\mathrm{CP})$.

Fig. 2. Effect of the diet formaldehyde on the amount of formaldehyde in the milk.
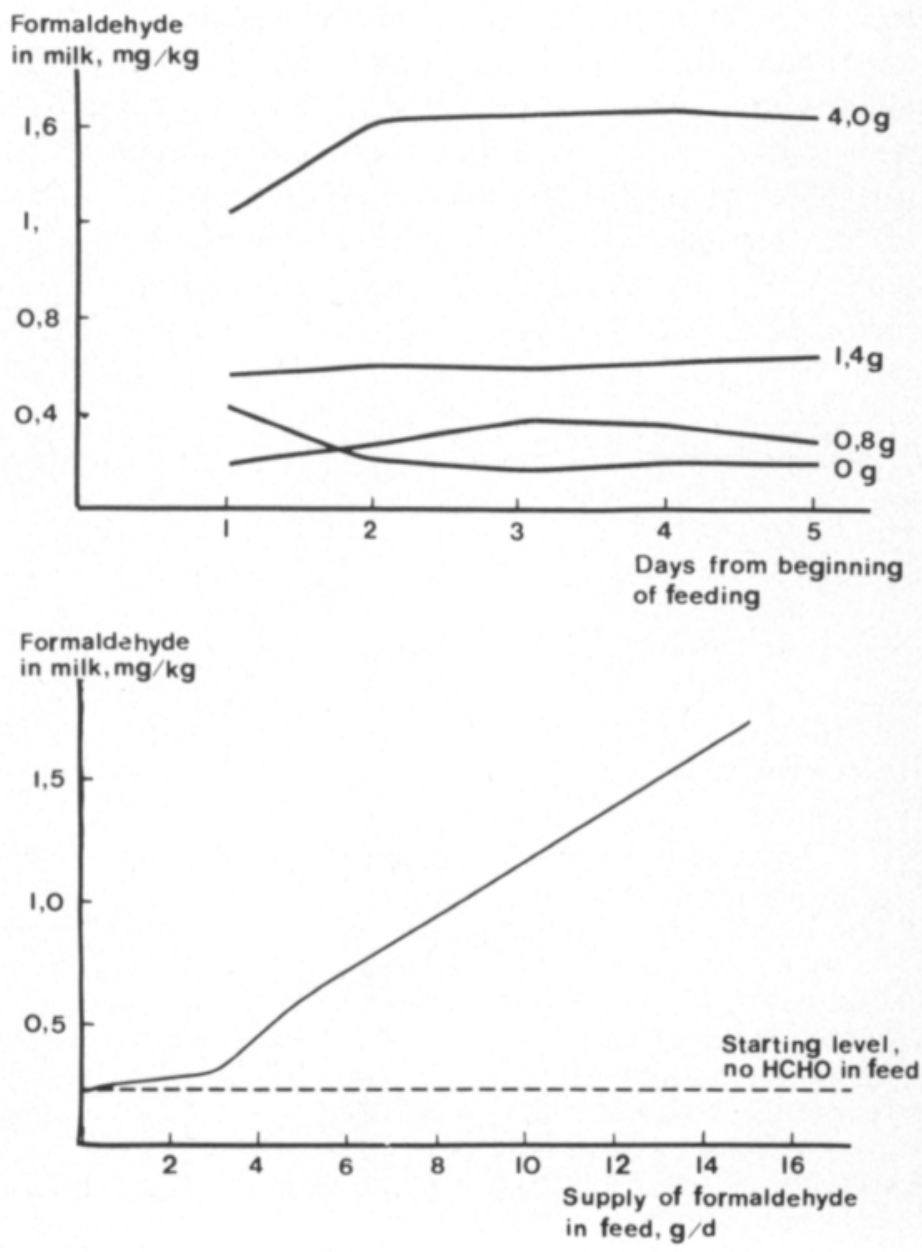
The amount of free formaldehyde in the protein concentrates was 26-30 $\%$ of the amounts added. The values for the different protein concentrates in the first to the last periods of the experiment were as follows: $\mathrm{HCHO}_{0.8} 28$, 28,27 and $26 \%, \mathrm{HCHO}_{1.4} 29,29,28$ and $26 \% \mathrm{HCHO}_{4.0}, 30,31,30$ and 29 $\%$.

The results showed that the formaldehyde content of the milk increased with the increase in the formaldehyde treatment level of the feeds. Similar results were obtained by BECK and GROSS (1973), KREULA and RAURAMAA (1976), and WRENN et al. (1976).

The transfer of formaldehyde from feed to milk in this experiment was $0.07 \%$. In the study of WRENN et al. (1976), where the concentrate mixture was treated with $1 \%$ of formaldehyde, the transfer was also small, never over $0.023 \%$. BECK and GROSS (1973) found that about $1 \%$ of the formaldehyde of the feed, formaldehyde-treated silage, was transferred to the milk, the formaldehyde content of the milk rising to $2.5 \mathrm{mg} / \mathrm{kg}$. In the study of KREULA and RAURAMAA (1976), cows fed with fresh-cut grass treated with formaldehyde gave milk with a formaldehyde content of $0.6-2.2 \mathrm{mg} / \mathrm{kg}$.

In this and some other studies (for instance WRENN et al. 1976) formaldehyde was recovered from the milk although it was not present in the feeds. But in other experiments no formaldehyde was recovered from the milk when untreated feeds were given (BECK and GROSS 1973. KREULA and RAURAMAA 1976, SYRJÄLÄ et al. 1978). According to FOGERTY and JOHNSON (1980), milk and some other foods contain at least small amounts of formaldehyde, generally less than $10 \mathrm{mg} / \mathrm{kg}$, but not necessarily in the form of free formaldehyde. It is probably released during the analyses. It also seems that the animals have individual differences in the occurrence of formaldehyde in the milk (SYRJÄLÄ-QVIST and SETÄLÄ 1982).

Acknowledgements. - We wish to express our best thanks to Mr. Alpo Salo for technical help during this study.

\section{References}

ANON, 1975. Association of Official Agricultural Chemists. Official Methods of Analysis. 12th Ed., Washington.

BECK, Th. \& GROSS, F. 1973. Zur Frage der Rückstande bei der Verwendung Formaldehydhaltiger Zusatzmittel bei der Gärfutterbereitung. Das Wirtschaftseigene Futter 19: 282-289.

BREIREM, K. 1969. Fôrnormer. K. K. Heje/Singsaas Lommealmanakk 1: 120. Oslo.

FOGERTY, A. C. \& JOHNSON, A. R. 1980. Influence of nutritional factors on the yield and content of milk fat protected polyunsatured fat in the diet. IDF Bulletin 125: 96-105.

KAEMMERER, K. \& KERBER, H. J. 1977. DLG-Forschungsberichte über Tierernährung Nr. 538004. Ref. Kaufmann \& Lüpping 1978.

KAUFMAN, W. \& LÜPPING, W. 1978. Forschritte beim geschützten Protein - ein Kurzbericht. Kraftfutter 10: 524-528. 
KREULA, M. \& RAURAMAA, A. 1976. Transfer of formaldehyde from feed to milk during the feeding of fresh cut grass treated with formaldehyde-containing preservative. J. Scient. Agric. Soc. Finl. 48: 154-157.

KREULA, M. \& RAURAMAA, A. 1977. Formaldehyde and $\mathrm{HCOOH}$ in the ensiling process and the metabolism of dairy cows. Agrochimica 21: 341-355.

SYRJÄLÄ, L., POUTIAINEN, E. \& KOSKELA, V.-H. 1978. Untreated and formaldehyde treated skimmilk powder as a protein supplement for dairy cows. J. Scient. Agric. Soc. Finl. 50: 155-165.

SYRJÄLÄ-QVIST, L. \& SETÄLÄ, J. 1982. Formaldehyde content of milk. 2. Cows fed on grass silage preserved with formaldehyde-containing additive and on formaldehyde-urea. J. Scient. Agric. Soc. Finl. 54: 69-76.

WRENN, T. R., WEYANT, J. R., WOOD, D. L. \& BITMAN, J. 1976. Increasing polyunsaturation of milk fats by feeding formaldehyde protected sunflower- soybean supplement. J. Dairy Sci. 59: $627-635$.

Ms received March, 241982.

\title{
SELOSTUS
}

\section{Maidon formaldehydipitoisuus. 1. Lehmien valkuaisväkirehu käsitelty lisääntyvillä formaldehydimäärillä.}

\author{
Liisa Syrjälä-Qvist ja Jouko Setälä \\ Helsingin yliopiston kotieläintieteen laitos, 00710 Helsinki 71
}

Tutkimuksessa selvitettiin maidon formaldehydipitoisuutta lehmien saadessa valkuaisväkirehua, joka oli käsitelty eri suuruisilla formaldehydimäärillä. Koe tehtiin neljällä lehmällä Latinalaisen neliön mukaan. Jokaisen koejakson pituus oli 10 pv. Lehmien keskituotos kokeen aikana oli 9.4 kg maitoa/pv.

Perusrehuina olivat heinä, olki ja jauhettu ohra. Valkuaisväkirehuseoksen, joka sisälsi mm. soijarouhetta, maitojauhetta, lihaluurehujauhoa, mäskijauhoa, melassia, melassileikettä ja ureaa, formaldehydikäsittelytasot eri dieeteillä olivat seuraavat:

1) käsittelemätön

2) $0.8 \mathrm{~g}$ formaldehydiä/100 g raakavalkuaista

3) $1.4 \mathrm{~g} \quad-$ - - -

4) $4.0 \mathrm{~g} \quad-$ -

Eläimet saivat ko. valkuaisväkirehuseosta $1500 \mathrm{~g} / \mathrm{pv}$. Koko rehuannoksen valkuaispitoisuus oli 14-15 $\%$ kuiva-aineesta. Formaldehydillä käsitellyn valkuaisen osuus tästä oli 41-50 \%.

Lehmät saivat eri dieeteillä formaldehydiä seuraavat määrät: 1) $0 \mathrm{~g} / \mathrm{pv}, 2) 2.9 \mathrm{~g} / \mathrm{pv}, 3) 5.1 \mathrm{~g} / \mathrm{pv}$ ja 4) 14.6 $\mathrm{g} / \mathrm{pv}$. Maidon formaldehydipitoisuudet olivat vastaavasti: 1) $0.2 \mathrm{mg} / \mathrm{kg}, 2) 0.3 \mathrm{mg} / \mathrm{kg}, 3) 0.6 \mathrm{mg} / \mathrm{kg}$ ja 4) $1.7 \mathrm{mg} / \mathrm{kg}$. Myös silloinkin, kun rehuun ei oltu lisätty formaldehydiä, löytyi sitä pieniä märiä maidosta. Rehuun lisätystä formaldehydistä siirtyi maitoon vain $0.06-0.07 \%$. Maidon formaldehydipitoisuus nousi mainituille tasoille kahdessa päivässä ja pysyi melko tasaisena koejakson ajan. 